\title{
Cougar Dispersal and Natal Homing in a Desert Environment
}

Author(s): http://orcid.org/0000-0002-0209-4640David M. Choate, http://orcid.org/0000-0001-6621-1271Kathleen M. Longshore and http:// orcid.org/0000-0002-7482-5254Daniel B. Thompson

Source: Western North American Naturalist, 78(2):221-235.

Published By: Monte L. Bean Life Science Museum, Brigham Young University https://doi.org/10.3398/064.078.0215

URL: http://www.bioone.org/doi/full/10.3398/064.078.0215

BioOne (www.bioone.org) is a nonprofit, online aggregation of core research in the biological, ecological, and environmental sciences. BioOne provides a sustainable online platform for over 170 journals and books published by nonprofit societies, associations, museums, institutions, and presses.

Your use of this PDF, the BioOne Web site, and all posted and associated content indicates your acceptance of BioOne's Terms of Use, available at www.bioone.org/page/ terms of use.

Usage of BioOne content is strictly limited to personal, educational, and non-commercial use. Commercial inquiries or rights and permissions requests should be directed to the individual publisher as copyright holder. 


\title{
Cougar dispersal and natal homing in a desert environment
}

\author{
David M. Choate ${ }^{1, *}$, Kathleen M. Longshore $^{2}$, and Daniel B. Thompson ${ }^{3}$ \\ ${ }^{1}$ School of Life Sciences, University of Nevada, Las Vegas, Box 454004, 4505 S. Maryland Pkwy., Las Vegas, NV 89154; \\ Western Ecological Research Center, United States Geological Survey, 160 N. Stephanie, Henderson, NV 89074 \\ ${ }^{2}$ Western Ecological Research Center, United States Geological Survey, 160 N. Stephanie, Henderson, NV 89074 \\ ${ }^{3}$ School of Life Sciences, University of Nevada, Las Vegas, Box 454004, 4505 S. Maryland Pkwy., Las Vegas, NV 89154
}

\begin{abstract}
We present a review of cougar dispersal literature and the first evidence of natural (i.e., unmanipulated) homing behavior by a dispersing male cougar (Puma concolor) that sustained severe injuries crossing the northern Mojave Desert. Based on Global Positioning System and ground tracking data, the male traveled a total distance of $981.1 \mathrm{~km}$ at $5.03 \mathrm{~km} / \mathrm{d}$, including $170.31 \mathrm{~km}$ from the Desert National Wildlife Refuge to the northwestern Grand Canyon, where he sustained severe injuries. The interkill interval increased from $7.1 \pm 2.7 \mathrm{~d}$ while he was in his natal range to $17.5 \pm 4.9 \mathrm{~d}$ during dispersal. While homing, the male appeared to consume only reptiles until he died, $33.7 \mathrm{~km}$ from his capture site. In desert environments where prey availability is low, homing behavior may be an important strategy for dispersing cougars, providing a mechanism for persistence when the best quality habitats they encounter are already occupied by adult residents. Therefore, managing for habitat connectivity can ensure successful homing as well as dispersal on a greater scale than has been previously suggested. Elucidating the mechanisms that trigger homing during dispersal may provide critical insight into animal movements often overlooked as mundane behavior.
\end{abstract}

RESUMEN.-Presentamos la primera evidencia de comportamiento de retorno al territorio natal (es decir, sin manipulación) de un puma macho en dispersión (Puma concolor), después de sufrir lesiones graves al cruzar el norte del desierto de Mojave. De acuerdo al Sistema de Posicionamiento Global y a los datos de rastreo terrestre, el macho viajó una distancia total de $981.1 \mathrm{~km}$, recorriendo $5.03 \mathrm{~km}$ el primer día, incluyendo $170.31 \mathrm{~km}$ desde el Refugio Nacional de Vida Silvestre del Desierto hasta el noroeste del Gran Cañón, donde sufrió heridas graves. El intervalo de enfrentamientos durante su dispersión aumentó a $7.1 \pm 2.7$ días, mientras que en su rango natal fue de $17.5 \pm 4.9$ días. Mientras se dirigía a su hábitat natural, el macho parece haber consumido únicamente reptiles hasta el día de su muerte a $33.7 \mathrm{~km}$ del sitio de captura. En los ambientes desérticos donde la disponibilidad de presas es baja, el comportamiento de retorno al territorio natal podría ser una estrategia importante de dispersión de los pumas, proporcionando un mecanismo de supervivencia, cuando los hábitats de calidad que encuentran ya están ocupados por residentes adultos. Por lo tanto, la gestión de conexión del hábitat es esencial para garantizar el éxito del retorno al territorio natal, así como la dispersión a una escala mayor de lo que se ha recomendado anteriormente. El esclarecer los mecanismos que provocan el retorno al hábitat natural durante la dispersión podría proporcionar una visión crítica de los movimientos de los animales, que son frecuentemente ignorados como un comportamiento mundano.

Homing behavior is defined by movement that enables an animal to return to a previously occupied site, such as a home range or breeding ground, after displacement to an unfamiliar area (Papi 1992). Widely documented in vertebrate species (reviewed in Papi 1992) (e.g., territorial wolves, Canis lupus_-Bradley et al. 2005; black bears, Ursus americanus - Landriault et al. 2006; lizardsScali et al. 2013; and intertidal fish-White and Brown 2013), homing behavior is hypothesized to impart significant fitness advantages by ensuring access to resources when animals return to familiar areas (Bovet 1992). However, site fidelity required by homing may also lead to increased competition among close relatives for limited resources. In contrast, dispersal is the directional movement of an organism away from its natal range to an independent home range (Howard 1960, Greenwood 1980). The fitness benefits of dispersal include avoidance of competition or inbreeding and can result in improved gene flow, recolonization of vacant habitat, and recovery of sink populations (Chepko-Sade and Halpin 1987, Stoner et al. 2006, 2013). For

\footnotetext{
*Corresponding author: choate.davidm@gmail.com 
mammals, dispersal is typically male-biased, such that females tend to favor philopatry while males generally disperse (Greenwood 1980). While natal dispersal occurs once in an animal's lifetime after a period of exploratory movement, homing can occur whenever an individual makes a unidirectional return to either a natal or adult home range after an excursion (reviewed in Papi 1992, Thibault and Bovet 1999). For mammals, homing occurs naturally either when animals migrate annually between independent home ranges or when they return from excursions (Bovet 1992). The key distinctions between homing and other exploratory movements are the relatively direct line of travel during the return, the use of routes that are not necessarily simple back-trails, and the lack of linkage to topographical corridors. Homing is critically linked to dispersal, representing either the return mechanism from training movements that provide an individual information about the environment before it emigriates, or a safety mechanism when an individual tests a hostile environment. Consequently, homing behavior provides an indication of how habitat features, distribution, and occupancy by resident individuals determine dispersal. Despite the important role of homing in understanding dispersal, detailed accounts of natural homing behavior are rare.

In the western hemisphere, the cougar (Puma concolor) is a large, obligate carnivore that follows a pattern of sex-biased dispersal. Based on radiotelemetry studies, most subadult males 10-33 months of age (up to $100 \%$ of local male offspring; Table 1) disperse from their natal range (Beier 1995, Sweanor et al. 2000, Maehr et al. 2002, Stoner et al. 2013). This male-biased dispersal in cougars could reduce inbreeding and competition (Logan and Sweanor 2001). Under this hypothesis, the fitness costs of remaining in the natal range outweigh the advantages of dispersal. Natural homing has only been implicitly described in cougar studies where individuals migrated (Pierce et al. 1999) or dispersed into habitat adjacent to their natal population after returning from circular, exploratory movements across a surrounding matrix of unsuitable habitat (Maehr et al. 2002, Morrison et al. 2015). Conversely, experimental evidence for successful homing by cougars has been found in adult (28-96 months) breeding individuals that were manually relocated $>300 \mathrm{~km}$ from their resident home ranges (Ruth et al. 1998). Of the 14 cougars (16-108 months old) translocated in the Ruth et al. (1998) study, 8 individuals moved in the general direction of the source population. Only 2 adult males returned to their previously established home ranges; one was able to reestablish his territory and the other died. Older individuals (>96 months) that were translocated did not move from release sites and were subsequently killed by other cougars. This demonstrates that homing can be induced by translocations, with the greatest potential benefits for those individuals with previously established home ranges. However, the conditions necessary to trigger homing behavior in natural populations are still not clearly understood. Homing behavior may be an important conditional strategy in environments with patches of low prey availability that are separated by large areas of unsuitable habitat and with high probabilities that the best quality habitats are already occupied by adult residents. Here, we first review the dispersal literature for explicit evidence of homing by cougars, particularly cases wherein homing occurred after individuals sustained severe injuries. Next, we present the first detailed evidence of natural (i.e., unmanipulated) homing behavior by a dispersing male cougar traversing a desert environment. In addition, we document evidence of prey capture within the local sites used during dispersal and describe the habitat conditions associated with this behavior.

We conducted a search using the search engines Web of Knowledge/Web of Science (Clarivate Analytics, Philadelphia, PA) and Science Citation Index Expanded (Clarivate Analytics), and the terms "Puma concolor," "Felis concolor," "homing," "dispersal," and their variants to generate a list of peerreviewed literature. The initial set of 81 papers was then examined to select those that provided descriptive data on the dispersal and or natural homing behavior of cougars (i.e., excluding translocations). We then compiled the papers that provided quantitative figures on the number and sex of individuals that dispersed, dispersal distances, duration of dispersal movements, and related parameters. Only 23 papers derived from 18 independent study sites across North America provided sufficient information for comparison (Table 1). 


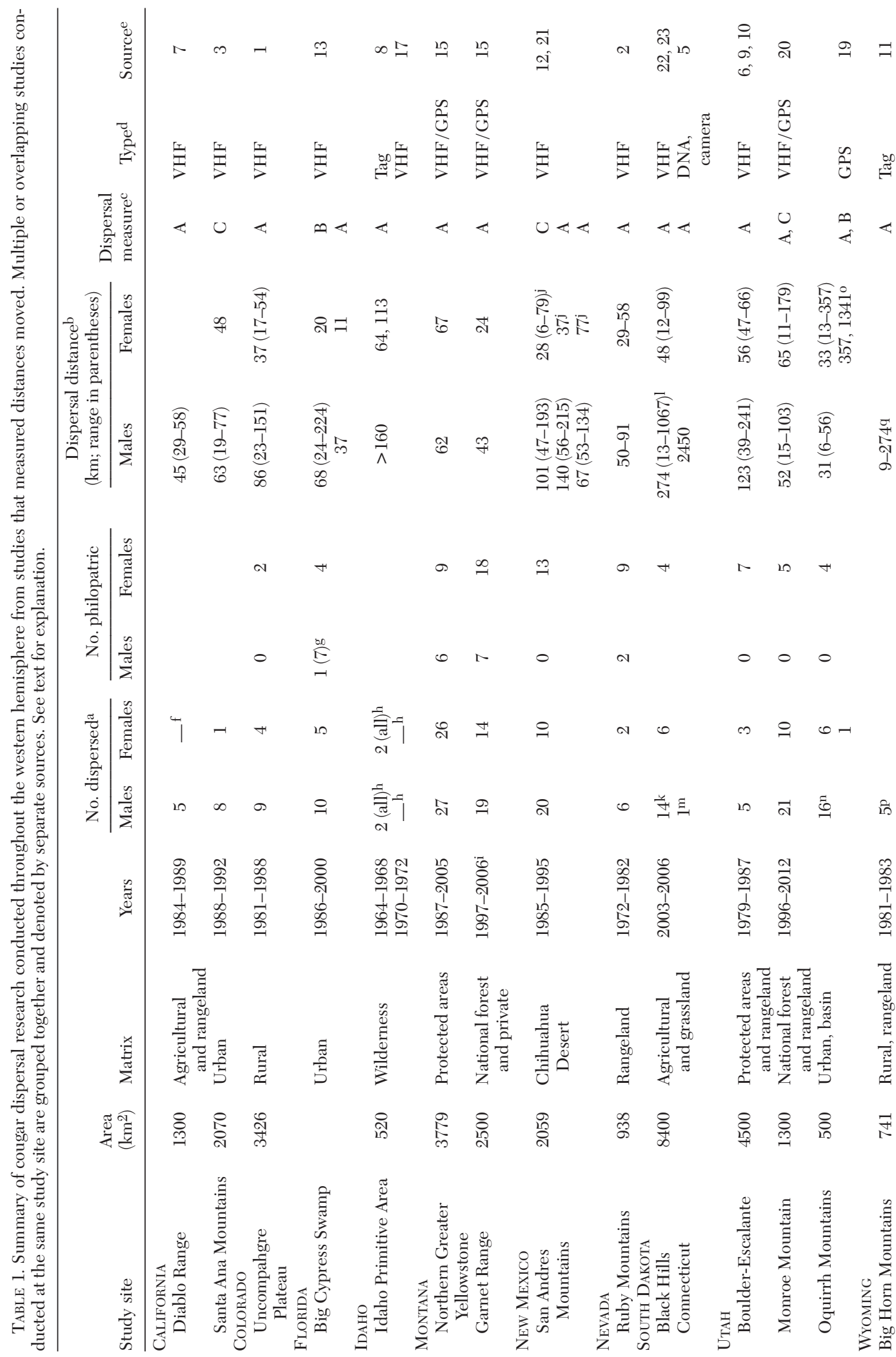




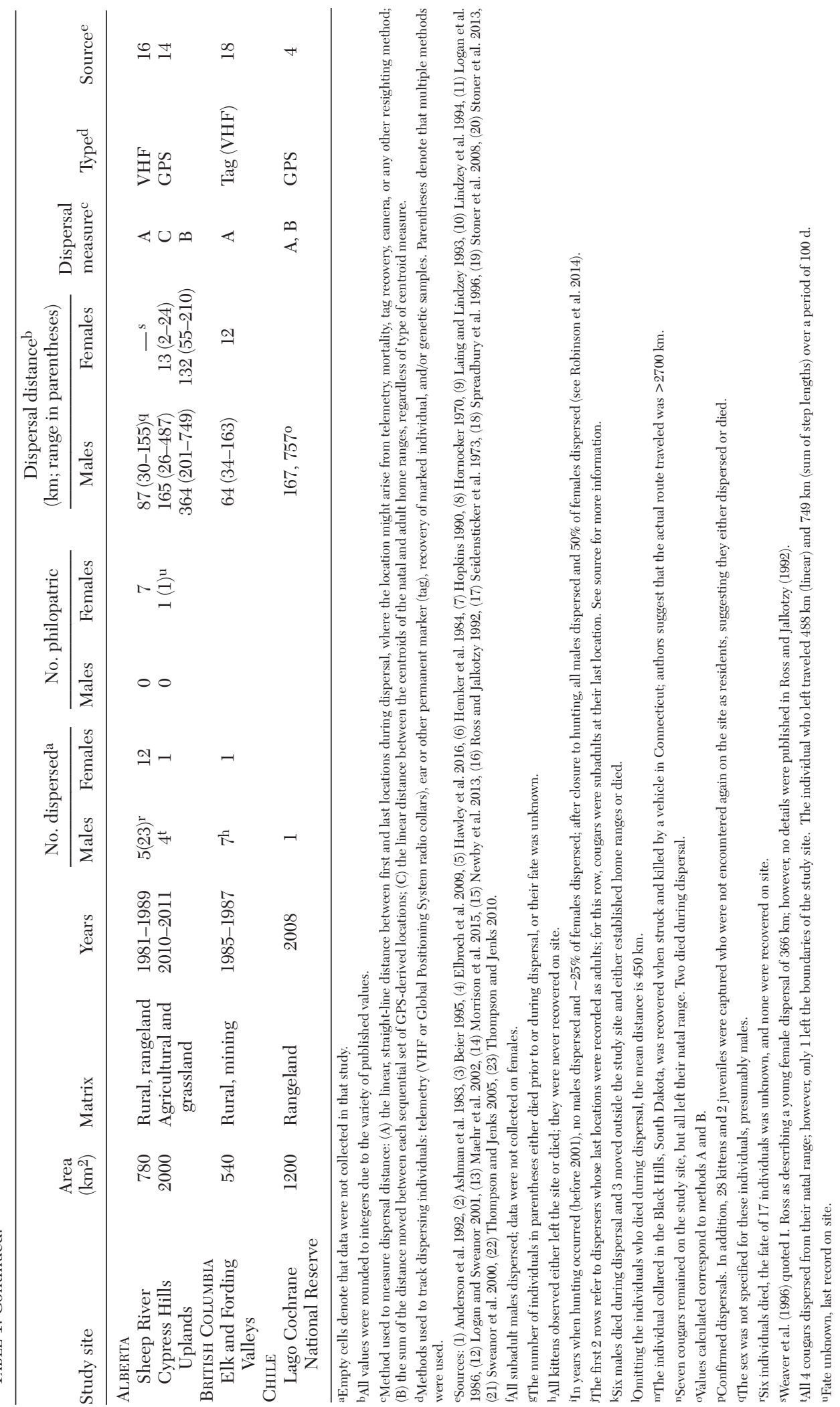


Few studies provided information on each individual observed; thus some values are presented as ranges or summary statistics. These data included individual records on 197 male and 187 female cougars, of which $92.4 \%$ of males and $55.6 \%$ of females dispersed. Dispersal distances varied greatly, from $6 \mathrm{~km}$ to $>2450 \mathrm{~km}$ in males and from $2 \mathrm{~km}$ to $1341 \mathrm{~km}$ in females (Table 1, see footnotes for methods), with mean values (derived across study means) of $110 \mathrm{~km}$ for males and $45.4 \mathrm{~km}$ for females, excluding the extreme long-distance records as outliers. Only 5 studies provided details on the duration of the dispersal movements, reporting on 15 males and 14 females, with a range of dispersal lasting 20-730 d. While several studies summarized the number of individuals who remained philopatric after movement bouts, none of the studies provided a detailed description of homing behavior. Circular movements constrained by urban development or other habitat features that thwarted dispersal were described for studies conducted in several regions (Beier 1995, Maehr et al. 2002, Riley et al. 2014). In other regions, the study populations were surrounded by unsuitable habitat that included open agriculture and grasslands (e.g., Hopkins 1990, Thompson and Jenks 2005, 2010), or in one case, Chihuahua Desert (Sweanor et al. 2000, Logan and Sweanor 2001). However, none described homing behavior associated with injury sustained by the dispersing individual. While this review does not indicate that homing is necessarily rare in cougars, it does demonstrate that there is a critical lack of information linking habitat distribution, features, and occupancy by cougars to dispersal through homing movements. Next, we describe an incidence of cougar homing behavior associated with trauma experienced during dispersal.

Encompassing $\sim 6540 \mathrm{~km}^{2}$, the Desert National Wildlife Refuge (DNWR) is the largest national wildlife refuge in the lower 48 United States, located just north of Las Vegas, Nevada $\left(36^{\circ} 46^{\prime} 00^{\prime \prime} \mathrm{N} 115^{\circ} 26^{\prime} 00^{\prime \prime} \mathrm{W}\right)$. Established in 1936 for the conservation of desert bighorn sheep (Ovis canadensis nelsoni), the DNWR was granted national wildlife refuge status in 1966. Since 1940, the western half of the refuge has been closed to the public for use as the Nevada Test and Training Range by the United States Air Force (Fig. 1).
We focused our field efforts on the eastern public access areas, including the Sheep Range, Las Vegas Range, East Desert Range, and Gass Peak $\left(\sim 3080 \mathrm{~km}^{2}\right)$. More than $83 \%$ of the refuge is proposed for wilderness status and is managed as de facto wilderness, with access limited to a few primitive roads. Located in the northeastern portion of the Mojave Desert, the DNWR and neighboring mountain ranges receive highly variable precipitation $(\sim 27-249$ $\mathrm{mm})$ that falls primarily $(\sim 82 \%)$ in winter and spring months (Oct-Apr), with the remainder falling in late summer (Jul-Oct, 0.5-125 mm; USGS 2004). Desert shrub was the dominant vegetation type throughout the region, characterized by creosote (Larrea tridentata), blackbrush (Coleogyne ramosissima), and saltbush (Atriplex spp.) associations on the bajadas and in valleys from 800 to $1800 \mathrm{~m}$ (Ackerman 2003; D.A. Charlet unpublished report). Mohave yucca (Yucca schidigera) and Joshua tree (Y. brevifolia) were common throughout blackbrush communities. Above $1800 \mathrm{~m}$, pinyon pine (Pinus monophylla) and Utah juniper (Juniperus osteosperma) formed sparse woodlands, including apache plume (Fallugia paradoxa), Mormon tea (Ephedra nevadensis), mountain mahogany (Cercocarpus ledifolius), and sagebrush (Artemisia spp.). Patches of coniferous forest occurred above $2200 \mathrm{~m}$ and comprised ponderosa pine (Pinus ponderosa), white fir (Abies concolor), and bristlecone pine (Pinus longaeva). Limestone ridges, cliffs, and outcrops were common, broken by long boulder- and cobble-strewn washes. Within the study area, guzzlers and developed springs provided the primary sources of perennial water. No hunting occurred on the refuge, with the exception of a special limited-entry annual hunt on male bighorn sheep. Mule deer (Odocoileus hemionus) and desert bighorn sheep were the primary prey available to cougars on the DNWR. Even though the DNWR is surrounded by Mojave Desert, the human population estimate for the adjacent Las Vegas Valley in Clark County was 2,069,681 in 2014 (www.census.gov).

All capture and handling techniques were performed in accordance with the guidelines of the American Society of Mammalogists for the use of live animals in research (Sikes et al. 2011) and followed protocols approved by the University of Nevada, Las Vegas, Institutional Animal Care and Use Committee under permit 


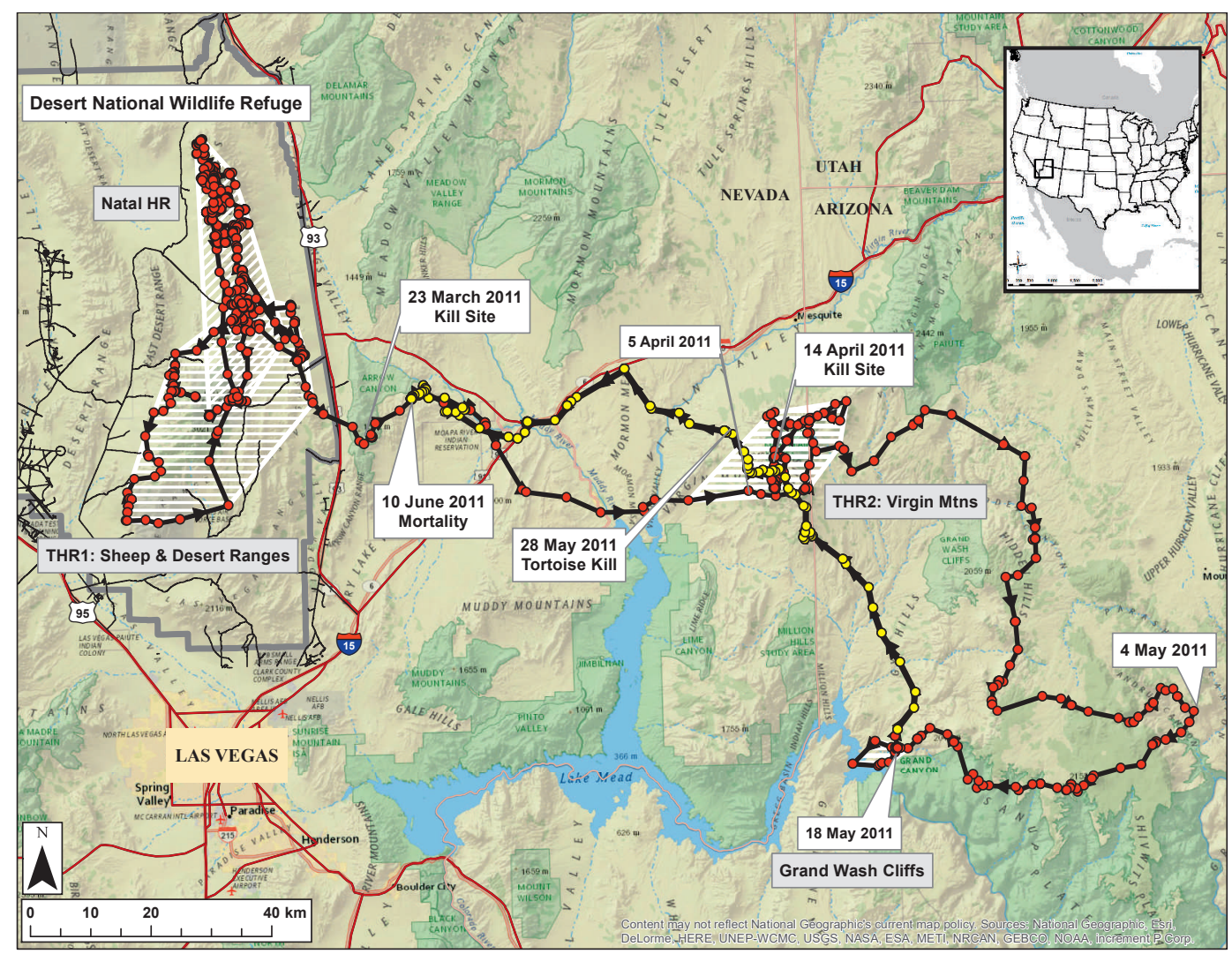

Fig. 1. Movements of a GPS-collared male cougar (M3) during dispersal from November 2010 to June 2011. These movements include unsuccessful homing (yellow points) toward the natal range on the Desert National Wildlife Refuge, Nevada, USA. Home ranges (hatched polygons) include M3's natal range (Natal HR) while he was still accompanied by his sibling and/or mother on the Sheep Range and 2 temporary home ranges: THR1, the first exploratory use of mountain ranges within an area that overlapped the natal range (i.e., on the Desert National Wildlife Refuge), and THR2, exploratory movements within the Virgin Mountains. M3 paused briefly at the Grand Wash Cliffs after reaching the farthest extent of dispersal on 4 May 2011 and likely encountering an adult male cougar.

R0610-257. Between 2010 and 2013 we captured cougars using hounds or snares during all seasons, excluding the hottest summer months (Jul-Sep). Adult ( $>3$ years) and subadult (1.5-3 years) cougars were fitted with Argos-equipped GPS collars (Telonics Gen4, Mesa, AZ) and unique eartags. Collars were programmed to acquire 6 locations per day at 04:00, 08:00, 12:00, 16:00, 20:00, and 24:00. We monitored daily Argos-delivered downloads throughout the study and attempted to investigate mortality signals within $24 \mathrm{~h}$ of receiving the data download. We examined cougar locations daily to identify clusters of locations that might suggest that a kill had been made (Anderson and Lindzey 2003, Knopff et al. 2009). A cluster was defined as $\geq 2$ points located within $200 \mathrm{~m}$ of each other within a 14-d period. Because starvation was a concern for cougars in this environment (see below), we did not visit a cluster while the cougar was still present but sought to investigate sites immediately after the individual left the site. We investigated prey remains at a cluster for evidence of cougar feeding behavior (e.g., carcass had been buried or cached, presence of cougar scats) and assigned a cause of death if it was possible to ascertain (e.g., evidence of crushed trachea with associated hemorrhaging and canine punctures). We differentiated scavenging events from predation when a cougar fed on a carcass that had been killed by something other than a cougar (e.g., road-killed bait), or if the carcass age differed 
greatly from the time period when the cougar was present. All radio collars were programmed to release remotely for retrieval. As part of an investigation into cougar-prey relations on the DNWR, we estimated cougar density and spatial use based on all location data from captures, telemetry data, track evidence, and photographs of marked and unmarked individuals at camera traps deployed at water sources, along trails, and at bait sites throughout the study site.

Cougar location data were plotted and analyzed using tools in ArcMap 10.0 (Esri 2010) and the Geospatial Modelling Environment (GME; Beyer 2012). We calculated mean hourly movement distances using GME to link consecutive point locations with straight lines. We estimated mean rates for missing locations by widening the time interval and calculating the distance between next available points. Mean daily movement rates were then derived for each identifiable behavior. Prior to establishing an adult home range, subadult cougars display transient behavior. Recently, Morrison et al. (2015) refined transience to include both natal dispersal (where animals never return to their natal range) and "exploratory forays." These exploratory periods include unidirectional movements interspersed with periods of localizing behavior, resulting in temporary home ranges (THRs; sensu Beier 1995). THRs are later abandoned but may be revisited. THRs that are abandoned represent aborted attempts to create a permanent home range (Stoner et al. 2008). Morrison et al. (2015) proposed that localizing events lasting fewer than $20 \mathrm{~d}$ could result from a feeding bout of a transient individual, whereas events exceeding $20 \mathrm{~d}$ should indicate that a cougar has found enough resources to establish a permanent home range (HR) (i.e., to include the possibility of multiple kill events [e.g., Morrison et al. 2015]). Lastly, we distinguished between homing behavior and other exploratory movements; homing is the relatively direct line of travel toward the natal home range where the return routes are not necessarily simple back-trails, nor are they linked to any topographical corridors or following specific landscape features. While transient behaviors related to dispersal may be circular or curvilinear in any direction, homing is always directed back to the natal home range. Consistent with Beier (1995), we derived minimum convex polygons (MCPs) and used these to delineate THRs, including a predispersal natal home range, when the subadult traveled intermittently with his mother and sibling. As a more conservative estimate related to intensity of use, we derived the same THRs using a 95\% kernel density estimate (KDE). We use the former to illustrate the extent of area used (Fig. 1) and the latter for analysis. We present descriptive data without statistical tests, given that the data describe movements of a single individual.

During the study, we captured 5 cougars on the DNWR (2 adult females, 2 subadult females, and 1 subadult male) and equipped them with radio collars. Based on all evidence, we estimated that a minimum of 12 cougars used the DNWR in 2010: 5 adults, 4 subadults, and 3 kittens $(<1.5$ years old). Of these individuals, at least 3 died due to starvation in 2011 (1 adult, 1 subadult female, and 1 or more kittens). No evidence was detected for the presence of new kittens or a resident adult male until late 2013. Consequently, cougar density on the site declined from $\sim 0.21-0.29$ adults and subadults per $100 \mathrm{~km}^{2}$ in 2010 to $\sim 0.07-0.13$ in 2013 . The male M3 was first captured using hounds on 28 November 2010 while traveling with his mother and a female sibling. M3 appeared in excellent condition, weighing $40.6 \mathrm{~kg}$ at capture, and was estimated to be 1-1.5 years old. During an attempt to capture his mother, M3 was recaptured in a snare on 1 February 2011. At this time he weighed $44.8 \mathrm{~kg}$ and still appeared in excellent condition. Based on track evidence, M3 began to travel independently in early February 2011, and at about 20:00 on 15 February 2011, his telemetry locations suggested he had left his natal range and begun to explore other parts of the DNWR (Fig. 1). The precise extent of M3's natal range could not be determined because we were unable to capture and collar his mother during the study, although we monitored her movements by tracking and photo captures at camera trap sites, which provided a conservative estimate of his natal range. After several extended movements across the DNWR, M3 left his natal mountain range on 22 March 2011 and crossed Hwy. 93 and $5.3 \mathrm{~km}$ of low-elevation bajadas to the neighboring Arrow Canyon Range. By 23 March 2011, he had killed an adult female bighorn sheep in this range. His next bighorn 
sheep kill occurred on 14 April 2011, after he had traveled a linear distance of $67.4 \mathrm{~km}$ to the Virgin Mountains. Although we continued to monitor M3's daily Argos-delivered data after investigating this kill site, limited resources prohibited investigating additional cluster sites until after his collar signaled a mortality event in the early morning of 12 June 2011. Field necropsy conducted on 13 June 2011 suggested that the proximate cause of death was starvation. However, numerous previous injuries were evident, including both partially healed and open punctures and lacerations, in addition to a broken rib. While the broken rib suggested a fall, signs indicative of a previous conflict with a cougar included a partially healed laceration to the cranium, lacerations to the left and right lumbar regions, and paired punctures to the right lumbar-spinal region indicative of canine bite wounds. All of these injuries displayed signs of tissue recovery or repair, suggesting that some time had passed since their occurrence and that they occurred at about the same time. In addition, the location and tissue damage for the single fracture did not appear consistent with trauma that might occur from a vehicle impact. No evidence of either a struggle or fall was present at the mortality site. These injuries suggested that a prior conflict with another cougar may have resulted in a weakened condition and possible septicemia. Lab results from tissues were inconclusive due to the rapid autolysis that occurs when tissues are exposed to ambient temperatures exceeding $37^{\circ} \mathrm{C}$. The only contents in the gastrointestinal tract were a lizard epidermis and several scutes from a desert tortoise (Gopherus agassizii) shell.

Data retrieved from the GPS collar included 949 locations, of which 564 (59.4\%) occurred on the DNWR and 397 (41.8\%) occurred while M3 was still traveling with his mother and/or sibling. Overall successful fix rate was $81 \%$. After analyzing data recovered directly from the GPS collar, we investigated additional clusters and locations near potential movement barriers (e.g., along the I-15 freeway) to infer details regarding M3's movements and behavior. During the 195 days of monitoring, M3 traveled a total distance of $981.10 \mathrm{~km}$ based on the sum of all step lengths, resulting in an average movement rate of $5.03 \mathrm{~km} / \mathrm{d}$. The greatest linear distance M3 traveled from his first capture location was $170.31 \mathrm{~km}$ to the southeast ending at the north rim of Grand Canyon National Park. From there, M3 traveled west then back to the northwest, eventually retracing his steps in a manner consistent with homing behavior. He died before returning to his natal mountain range. While monitored, M3's movements included exploration and use of THRs ( $n=2$ occasions), dispersal $(n=2$ occasions), and homing (1 route) (Fig. 1).

While traveling with his mother in the predispersal stage, M3 covered $242.4 \mathrm{~km}$ within his natal HR (MCP: $391.0 \mathrm{~km}^{2}$, KDE: $244.8 \mathrm{~km}^{2}$; Fig. 1). The mean interval between kills during this period was $7.14 \pm 2.7 \mathrm{~d}$ and kills consisted only of bighorn sheep. From 15 February to 21 March 2011, M3 traveled independently, based on both track and radio-telemetry evidence. During this period his movements localized on the DNWR, encompassing his first THR (MCP: $716.6 \mathrm{~km}^{2}$, KDE: $652.4 \mathrm{~km}^{2}$ ). Similar to values reported for dispersing males in Alberta $(\bar{x}=17.3 \%$ first THR overlap with adults; Morrison et al. 2015), $\sim 23.7 \%$ of this range overlapped his natal HR. During this stage on the DNWR, the interval between kills increased to $17.5 \pm 4.9 \mathrm{~d}$, and these kills were also bighorn sheep. Between 22 March and 5 April 2011, M3 began his first directional dispersal out of his natal mountain ranges on the DNWR and covered $89.07 \mathrm{~km}$ until he reached the Virgin Mountains, his next THR. This route included a successful crossing of Hwy. 93, Interstate 15 (I-15), 2 rivers, and several smaller paved roads. While crossing the Arrow Canyon Range, M3 killed a bighorn sheep. From 5 April to 22 April 2011, M3's movements localized in THR2 (MCP: $237.6 \mathrm{~km}^{2}$, KDE: $187.9 \mathrm{~km}^{2}$ ), where he killed another bighorn sheep. The mean interval between these kills was $20.5 \pm 3.5 \mathrm{~d}$, or $\sim 17 \mathrm{~d}$ within the Virgin Range. We considered this sufficient time to call the Virgin Range a THR, following Beier (1995). Beier (1995) first described THRs that lasted as little as $13-20 \mathrm{~d}$ and noted that these were typically the first THRs observed when individuals began dispersal, which was the case here with M3. Beier also noted that subsequent THRs increased in size until an HR was formed. This progression suggests that the process of dispersal may be adaptive, not fixed, depending on how the environmental conditions (i.e., habitat quality) determine the lag time until HR 


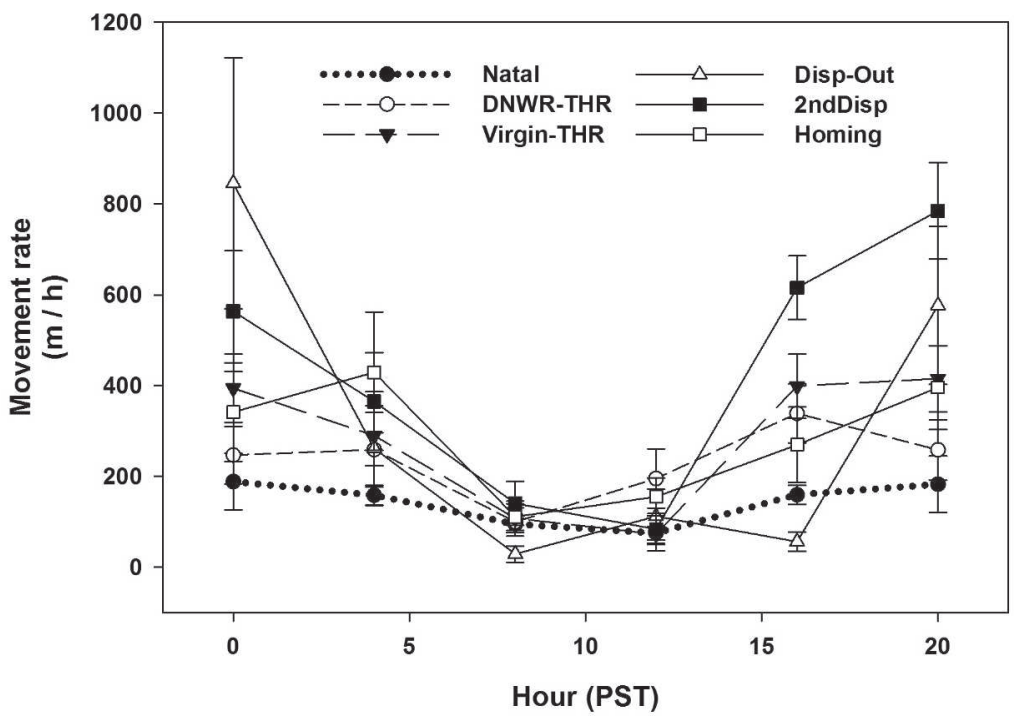

Fig. 2. Comparison of hourly movement rates (means \pm SE) during different phases of dispersal by a male cougar en route from and back to the Desert National Wildlife Refuge, Nevada, USA. Rates are estimated as the linear meters moved between consecutive GPS locations taken at 4-h intervals and plotted at the start of the interval (e.g., the hourly mean movement rate between 12:00 and 16:00 is plotted at 1200 $\mathrm{h}$ on the graph).

availability. Particularly in desert basin and range environments, single ranges might not hold enough prey to keep a cougar localized for $20 \mathrm{~d}$. Instead, individuals may move more frequently to adjacent ranges and still be within a HR. After leaving the Virgin Mountains, M3 traveled along a second circuitous dispersal route, reaching the western end of Grand Canyon National Park on 4 May 2011. From there he turned west, continuing until he reached the Grand Wash Cliffs on 12 May 2011. By this point he had covered $194.82 \mathrm{~km}$. M3 remained in this area $\left(\sim 20.5 \mathrm{~km}^{2}\right)$ for $6 \mathrm{~d}$. Investigation of locations within this area revealed the use of bighorn sheep bedding sites on cliff ledges, but no evidence of a kill or other interactions. Necropsy evidence (see above) suggested that M3 had received his injuries in an encounter with another cougar, while lack of evidence of other cougars at locations within this area indicated that the injuries may have occurred east of (i.e., prior to M3 arriving at) the Grand Wash Cliffs, likely sometime between 4 May and 12 May 2011. We suspect that rather than localized exploratory movements, the time M3 spent here represented a period when he attempted to recover from his injuries. Upon leaving this site on 18 May, M3 also had the possibility of closing a loop back toward his easternmost location on 4 May, thereby beginning exploratory movements associated with a new THR, or continuing in any of several directions. Instead, it is here that M3 turned north and traveled directly back toward his natal range until he died on 11 June 2011. M3 covered $150.39 \mathrm{~km}$, directly crossing a Mojave Desert landscape irrespective of topography or other natural features (i.e., not following drainages, ridges, etc.). During this 24-d period, the largest prey item he killed and consumed was a desert tortoise. At I-15, his route turned west and followed along the interstate within $\sim 0.9 \mathrm{~km}$, until crossing a paved road (169) near the Overton, Nevada, interchange. Rather than follow this road north to cross I-15, he continued west to a patch of riparian vegetation in the Muddy River, south of I-15 at Glendale, Nevada. He remained in this cover for $\sim 8-12 \mathrm{~h}$, then continued to the south and eventually crossed I-15 near the next interchange, $3.6 \mathrm{~km}$ southwest of Glendale. In the Moapa Valley, M3 appeared to retrace his earlier route until he died, approximately 9.08 linear $\mathrm{km}$ northeast from the site of his earlier sheep kill in the Arrow Canyon Range.

As would be expected for a predominantly nocturnal carnivore (Beier et al. 1995, Sweanor et al. 2008), diel activity times were highest during crepuscular hours (Fig. 2), but absolute 


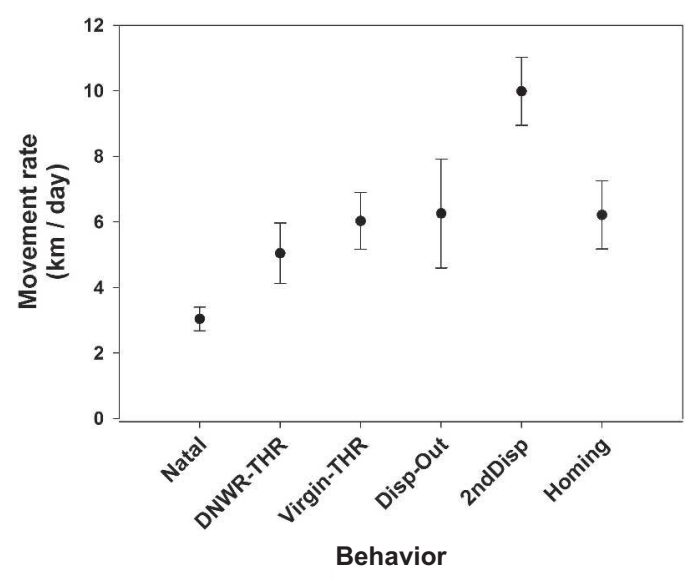

Fig. 3. Diel distances moved (means $\pm \mathrm{SE}$ ) during different stages of dispersal by a male cougar while en route from and back to the Desert National Wildlife Refuge $(\mathrm{DNWR})$, Nevada, USA. THR = temporary home range, 2ndDisp $=$ second dispersal bout. See text for full accounts of dispersal stages.

movement varied across behaviors (Fig. 3). Movement rates during dispersal and homing (range $6.22-9.99 \mathrm{~km} / \mathrm{d}$ ) were greater than those at THRs (range $3.04-6.03 \mathrm{~km} / \mathrm{d}$ ). M3 traveled fastest during his second dispersal bout; however, rates did not differ between dispersal and homing (Fig. 2), likely a consequence of his injuries. Hourly movement rates $(\mathrm{m} / \mathrm{h})$ were greatest during dispersal behaviors between 20:00 and 24:00.

After crossing a linear distance of 170.31 $\mathrm{km}$ to the northwestern end of Grand Canyon National Park, M3 displayed the first evidence of natural homing by a cougar traveling across the Mojave Desert back toward his natal home range after sustaining severe injuries from another cougar. This suggests a flexible strategy for dispersing males when they encounter occupied habitat. By returning to their natal range, subadult males might have a better chance for survival, consistent with male-biased dispersal, if there is a male vacancy in their familiar natal range. In this case, the risk of inbreeding if young males settle near their mother's natal range might be less than the risk of being killed by other males or starving in poor-quality habitats. Experiencing the latter conditions while dispersing might in turn trigger homing behavior. Evidence of natural homing is typically less common in carnivores (Höner et al. 2005), with the exception of seasonal home range shifts in conjunction with prey movements (Ballard et al. 1997, Carmichael et al. 2001). For example, evidence of migratory behavior has been demonstrated by cougars in a single population (Pierce et al. 1999), where some resident females moved between spatially distinct home ranges while following migratory deer herds.

Exploratory, short-term movements into a matrix of unsuitable habitat have been described for dispersing cougars (e.g., Florida panther and cougars in Saskatchewan) prior to their establishing home ranges adjacent to their natal populations (Maehr et al. 2002, Morrison et al. 2015). Due to its position at the end of a highly developed peninsula, the Florida panther population is separated by $>2000 \mathrm{~km}$ from the next nearest cougar population (Maehr et al. 2002). Despite long dispersals, male movements were bounded by natural and anthropogenic barriers, resulting in short effective dispersal distances. Similarly, extensive agriculture and grasslands surround a recently recolonized cougar population in southwestern Saskatchewan, where all male cougars dispersed from their natal ranges in the insular Cypress Hills Uplands. However, after navigating the extensive region surrounding these hills, all males but one established home ranges adjacent to the source population (Morrison et al. 2015). Cougar movements in these cases could best be described as circuitous, as opposed to the relatively linear, direct return to a previously occupied home range. While the subset of these movements that result in direct returns to natal or temporary HRs also fall under the rubric of homing behavior, the specific mechanisms leading to homing differ from M3's dispersal pattern. In these 2 examples, dispersing males explored environments different from their source populations without finding sufficient space or resources to establish a home range (i.e., the next suitable habitat patch) or after being thwarted by anthropogenic barriers (e.g., urban development) that led them to turn back towards previous home ranges. The DNWR also rests in a matrix of unsuitable desert, bounded on the south by Las Vegas, one of the fastest growing metropolitan areas in the United States (6.1\% growth rate in 2010-2014, U.S. average growth rate: $3.3 \%$, www.census.gov). During M3's exploratory movements, he encountered 
widely distributed patches of suitable, albeit low-quality habitat (i.e., similar to that available on the DNWR). Even though he might have established residence by incorporating these areas where other cougars occur, he instead returned directly to the DNWR after being severely injured, without following topography or specific habitat features. This raises the question of whether thwarted dispersal will lead to a specific type of homing behavior, and under what conditions this homing is likely to occur. For M3, these conditions likely included encounters of occupied habitat in a low-quality environment and a triggering mechanism of being severely injured.

The paucity of natural homing examples for dispersing carnivores might arise from limited sampling (i.e., low numbers of individuals or frequency of observations), undersampling of environments conducive to homing (i.e., differences in environmental productivity), or simply failure to describe the precise conditions leading to direct return movements. Prior to use of GPS technology enabling high-frequency sampling of locations, incidences of homing behavior may have been overlooked, because researchers assumed that marked animals recaptured near their natal range had not dispersed from their natal population. Highintensity sampling from an increasing number of studies generally refutes this hypothesis and supports greater dispersal distances and lack of homing by male cougars (Sweanor et al. 2000, Thompson and Jenks 2005, 2010, Stoner et al. 2008, 2013). However, this lack of evidence for homing may also reflect conditions in the predominantly more productive environments where these studies were conducted or the lack of intraspecific competition in areas where there are few cougars. In environments with low prey availability such as the northern Mojave Desert, where the best quality habitats are patchy, widely dispersed, and likely to be occupied by adult cougars due to competition for limited resources, homing behavior may occur more frequently than has been reported.

For carnivores, homing behavior is most often observed following deliberate translocation efforts by managers moving individuals to new areas in order to alleviate depredation pressure (i.e., on livestock, pets, agriculture; Bradley et al. 2005, Landriault et al. 2006), reduce potential threats to human safety (Blanchard and Knight 1995), or assist in population recovery by reintroductions (Belden and Hagedorn 1993, Ruth et al. 1998, Clark et al. 2002, Wear et al. 2005). Under these artificial conditions, individuals with established home ranges and greatest access to resources (i.e., adult residents) are the most likely to home (e.g., Ruth et al. 1998). In contrast, for naturally dispersing individuals, homing behavior could provide a mechanism for persistence of adult males when dispersal is thwarted by the presence of resident males in the next nearest available habitats. As such, it would be a conditional movement behavior compatible with the hypothesis of adaptive male-biased dispersal. For example, if intrasexual competition drives male dispersal (Logan and Sweanor 2001), then as male density declines or turnover rate increases, male dispersal rate should decline. This prediction has not been supported in more productive environments (Logan and Sweanor 2010, Stoner et al. 2013), more productive deserts (e.g., the Chihuahuan Desert; Logan and Sweanor 2001), or here where the natal environment supported fewer prey and cougars. M3 dispersed from the DNWR despite the absence of an adult resident male on the site during his dispersal. The absence of a resident male resulted in the lack of reproduction on the DNWR for a period of at least 2 years, despite the presence of $\geq 3$ independent adult females. However, by leaving their natal range, dispersing males reduce the likelihood of breeding with related females. For M3, homing was likely triggered after receiving severe injuries, when the potential survival benefits of returning to the natal range were apparently greater than the potential fitness costs of inbreeding. Competitor avoidance and inbreeding reduction are complementary hypotheses for male-biased dispersal; therefore, dispersal may be ultimately driven by inbreeding reduction but may still be modified based on competitor avoidance.

Observed daily movement rates (Fig. 3) were similar to rates recorded for male cougars in other studies $(\sim 5.4 \mathrm{~km} / \mathrm{d}$, Beier et al. 1995, Maehr et al. 2002), including a male with one of the longest recorded linear dispersal distances of $1067 \mathrm{~km}$ (i.e., $\sim 4 \mathrm{~km} / \mathrm{d}$-Thompson and Jenks 2005; based on genetic evidence, the longest distance is $>2450 \mathrm{~km}$-Hawley et al. 2016). Similarly, daily movement rates during dispersal and homing were greater than those within THRs. Even though we 
expected the highest mean daily movement rate during the most linear movement of homing, this rate may have been lower due to M3's injuries. During exploratory movements within THRs, the daily movement rate overlapped reported values for dispersing males (Morrison et al. 2015) and the value for a female cougar $(3.8 \mathrm{~km} / \mathrm{d})$ with the longest recorded actual dispersal distance of $1341 \mathrm{~km}$ (Stoner et al. 2008). Reduced movement rates within THRs were consistent with a change to hunting behaviors.

Even though subadult male cougars have been documented using THRs during dispersal (Beier 1995, Logan and Sweanor 2001, Morrison et al. 2015), here we document the first evidence of prey capture within THRs. During dispersal, M3 continued to kill bighorn sheep, albeit less frequently (i.e., greater interkill interval) than observed while he was in the presence of his mother. Overall, the only prey species taken by M3 were bighorn sheep, a tortoise, and lizards. The tortoise was found at a location cluster, suggesting that we may have only failed to detect smaller prey (e.g., rodents, lizards). Even though sheep are the most abundant prey in the region, this individual's use of sheep occurred despite the presence of mule deer that were preferentially selected by female cougars in the DNWR (D.M. Choate, USGS Western Ecological Research Center, unpublished data). Whether this selection would have continued if M3 had not been injured is unclear; however, in this Mojave Desert/Basin and Range environment, selective predation by dispersing males may influence predator movement patterns, as well as impact isolated bighorn herds. Stochastic predation events by individual predators can disproportionately affect population persistence (Festa-Bianchet et al. 2006, BourbeauLemieux et al. 2011), which suggests that management actions should target specific individuals whose predation may be predicted by maternal effects (Ross et al. 1997, Ernest et al. 2002).

Previous encounters by hunters in the Virgin Mountains indicated the presence of an adult male within THR2 (Pat Cummings, Nevada Division of Wildlife, personal communication). A subsequent encounter with that male or his sign (i.e., scrapes, scent) may have prompted M3 to leave that range and continue moving in an attempt to avoid the resident male. His encounter with another male and his injuries might have triggered a change in trajectory and subsequent switch to homing behavior. Consequently, M3's postdispersal movements both support the competitive avoidance hypothesis while he was dispersing and displaying homing behavior towards his natal area. When adult males already occupy the nearest suitable habitats, subadults might have a better chance of survival by returning to their natal range.

Successful conservation and management of carnivore populations benefit from an understanding of individual movement behavior across unsuitable habitat, particularly given the increasing rate of human expansion and concomitant landscape fragmentation during urban development. While both the longdistance dispersal capability and the successful navigation of conservation barriers (e.g., high-use roads, urban landscapes) have been demonstrated for cougars (Sweanor et al. 2000, Thompson and Jenks 2005, Stoner et al. 2008), understanding how frequently these events result in successful recruitment remains an important concern, especially for isolated, low-density populations (Riley et al. 2006, 2014). Similarly, where populations are isolated by matrices that vary in habitat quality, rates of homing may vary. The ways that increasing distance and decreasing habitat quality between populations influence the rate of dispersal might also provide insight into the frequency of homing behavior. For example, when individuals establish home ranges adjacent to their natal population or home range, should this be considered dispersal or a variant of homing, particularly after extensive excursions into unsuitable habitat? With the eastward expansion of cougar populations (LaRue et al. 2012, Hawley et al. 2016), should we expect to see more homing events than successful eastward dispersals? Even if rare, homing behavior may provide an underappreciated mechanism for male persistence and population recruitment that would result in unexpected reductions in gene flow. In environments defined by exceptionally low productivity, where fragmentation is the result of extensive regions of unsuitable habitat as well as anthropogenic barriers, managers may need to consider an even greater scale of movement and connectivity among isolated mountain ranges when delineating management units. 
Under these conditions, the metapopulation concept may be particularly relevant.

\section{ACKNOWLEDGMENTS}

This research was funded through a U.S. Fish and Wildlife Service Cooperative Ecosystem Studies Unit, Agreement No. 84320-5J306, and represents a collaborative effort between researchers at the University of Nevada, Las Vegas; the U.S. Geological Survey, Western Ecological Research Center; the University of California, White Mountain Research Station; the Nevada Department of Wildlife; and the U.S. Fish and Wildlife Service. We especially thank refuge manager Amy Sprunger, desert complex biologist Dr. Laurie Simons, biologist Lindsay Smythe, and the staff of the Desert National Wildlife Refuge for their extensive support; Brian Jansen for capturing cougars; and Sara Schuster and Matt Simes for assistance with fieldwork. We appreciate the many professionals, researchers, and volunteers who contributed to this project, including Marcus Bianco, Jeff Brown, Pat Cummings, Angelique Curtis, Matt Jeffres, Diego Johnson, Chris Lowery, and Dr. Peregrine Wolff. We thank Lisa Lyren and 2 anonymous reviewers for their critical review of the manuscript. The use of trade, product, or firm names in this publication is for descriptive purposes only and does not imply endorsement by the U.S. Government.

\section{Literature Cited}

Ackerman, T.L. 2003. A flora of the Desert National Wildlife Refuge. Mentzelia 7:1-90.

Anderson, A., D.C. Bowden, And D.M. Kattner. 1992. The puma on the Uncompahgre Plateau, Colorado. Colorado Division of Wildlife Technical Publication 40, Denver, CO. 116 pp.

Anderson, C.R., JR., AND F.G. LindZEy. 2003. Estimating cougar predation rates from GPS location clusters. Journal of Wildlife Management 67:307-316.

Ashman, D., G.C. Christensen, M.L. Hess, G.K. TsukaMOTO, AND M.S. WiCKERShAM. 1983. The mountain lion in Nevada. Nevada Fish and Game Department, P-R Proj.W-48-15 Final Report. 75 pp.

Ballard, W.B., L.A. Ayres, P.R. Krausman, D.J. Reed, AND S.G. FANCY. 1997. Ecology of wolves in relation to a migratory caribou herd in northwest Alaska. Wildlife Monographs 135:5-47.

BeIER, P. 1995. Dispersal of juvenile cougars in fragmented habitat. Journal of Wildlife Management 59:228-237.

Beier, P., D. Choate, and R.H. Barrett. 1995. Movement patterns of mountain lions during different behaviors. Journal of Mammalogy 76:1056-1070.
BELDEn, R.C., AND B.W. Hagedorn. 1993. Feasibility of translocating panthers into northern Florida. Journal of Wildlife Management 57:388-397.

Beyer, H.L. 2012. Geospatial Modelling Environment. Version 0.7.2.0. www.spatialecology.com/gme/index .htm

BlanCHARD, B.M., AND R.R. KNight. 1995. Biological consequences of relocating grizzly bears in the Yellowstone Ecosystem. Journal of Wildlife Management 59:560-565.

Bourbeau-Lemieux, A., M. Festa-Bianchet, J.M. GailLARD, AND F. PELLELTIER. 2011. Predator-driven component Allee effects in a wild ungulate. Ecology Letters 14:358-363.

Bovet, J. 1992. Mammals. Pages 321-361 in F. Papi, editor, Animal homing. Chapman \& Hall, London.

Bradley, E.H., D.H. Pletscher, E.E. Bangs, K.E. Kunkel, D.W. Smith, C.M. Mack, T.J. Meier, J.A. Fontaine, C.C. NiEmeyer, AND M.D. Jimenez. 2005. Evaluating wolf translocation as a nonlethal method to reduce livestock conflicts in the northwestern United States. Conservation Biology 19:1498-1508.

Carmichael, L.E., J.A. Nagy, N.C. Larter, and C. STROBECK. 2001. Prey specialization may influence patterns of gene flow in wolves of the Canadian Northwest. Molecular Ecology 10:2787-2798.

Chepko-Sade, B.D., AND Z.T. HaLPIN. 1987. Mammalian dispersal patterns: the effects of social pressure on population genetics. University of Chicago Press, Chicago, IL.

Clark, J.D., D. Huber, and C. Servheen. 2002. Bear reintroductions: lessons and challenges. Ursus 13: 335-345.

Elbroch, M., H.U. Wittmer, C. Saucedo, and P. Corti. 2009. Long-distance dispersal of a male puma (Puma concolor puma) in Patagonia. Revista Chilena de Historia Natural 82:459-461.

[Esri] Environmental Systems Research Institute. 2010. ArcGIS 10.0 desktop. Environmental Systems Research Institute.

Ernest, H.B., E.S. Rubin, And W.M. Boyce. 2002. Fecal DNA analysis and risk assessment of mountain lion predation of bighorn sheep. Journal of Wildlife Management 66:75-85.

Festa-Bianchet, M., T. Coulson, J.M. Gaillard, J.T. HogG, AND F. Pelletier. 2006. Stochastic predation events and population persistence in bighorn sheep. Proceedings of the Royal Society B-Biological Sciences 273:1537-1543.

Greenwood, P.J. 1980. Mating systems, philopatry and dispersal in birds and mammals. Animal Behaviour 28:1140-1162.

Hawley, J.E., P.W. Rego, A.P. Wydeven, M.K. Schwartz, T.C. Viner, R. KaYs, K.L. PILGRIM, AND J.A. JENKS. 2016. Long-distance dispersal of a subadult male cougar from South Dakota to Connecticut documented with DNA evidence. Journal of Mammalogy 97:1435-1440.

Hemker, T.P., F.G. Lindzey, and B.B. Ackerman. 1984. Population characteristics and movement patterns of cougars in southern Utah. Journal of Wildlife Management 48:1275-1284.

Höner, O.P., B. Wachter, M.L. East, V.A. Runyoro, and H. HofER. 2005. The effect of prey abundance and foraging tactics on the population dynamics of a social, territorial carnivore, the spotted hyena. Oikos 108:544-554. 
Hopkins, R.A. 1990. The ecology of the puma in the Diablo Range, California. Doctoral dissertation, University of California, Berkeley, CA.

Hornocker, M.G. 1970. An analysis of mountain lion predation upon mule deer and elk in the Idaho primitive area. Wildlife Monographs 21:1-39.

HowarD, W.E. 1960. Innate and environmental dispersal of individual vertebrates. American Midland Naturalist 63:152-161.

KnopfF, K.H., A.A. KnopfF, M.B. Warren, and M.S. BoycE. 2009. Evaluating Global Positioning System telemetry techniques for estimating cougar predation parameters. Journal of Wildlife Management 73:586-597.

LAING, S.P., AND F.G. LiNDZEY. 1993. Patterns of replacement of resident cougars in southern Utah. Journal of Mammalogy 74:1056-1058.

Landriault, L.J., M.N. Hall, J. Hamr, and F.F. Mallory. 2006. Long-range homing by an adult female black bear, Ursus americanus. Canadian Field-Naturalist 120:57-60.

LaRue, M.A., C.K. Nielsen, M. Dowling, K. Miller, R. Wilson, H.G. ShaW, and C.R. Anderson JR. 2012. Cougars are recolonizing the midwest: analysis of cougar confirmations during 1990-2008. Journal of Wildlife Management 76:1364-1369.

Lindzey, F.G., W.D. Van Sickle, B.B. Ackerman, D. Barnhurst, T.P. Hemker, and S.P. LaIng. 1994. Cougar population dynamics in southern Utah. Journal of Wildlife Management 58:619-624.

Logan, K.A., L.L. Irwin, AND R. SKInNER. 1986. Characteristics of a hunted mountain lion population in Wyoming. Journal of Wildlife Management 50: $648-654$.

Logan, K.A., and L.L. Sweanor. 2001. Desert puma: evolutionary ecology and conservation of an enduring carnivore. Island Press, Washington, DC.

Logan, K.A., AND L.L. Sweanor. 2010. Behaviour and social organization of a solitary carnivore. Pages 105-117 in M.G. Hornocker and S. Negri, editors, Cougar ecology and conservation. University of Chicago Press, Chicago, IL.

Maehr, D.S., E.D. Land, D.B. Shindle, O.L. Bass, and T.S. Hoctor. 2002. Florida panther dispersal and conservation. Biological Conservation 106:187-197.

Morrison, C.D., M.S. Boyce, and S.E. Nielsen. 2015. Space-use, movement and dispersal of sub-adult cougars in a geographically isolated population. PeerJ 3:e1118.

Newby, J.R., L.S. Mills, T.K. Ruth, D.H. Pletscher, M.S. Mitchell, H.B. Quigley, K.M. Murphy, and R. DeSimone. 2013. Human-caused mortality influences spatial population dynamics: pumas in landscapes with varying mortality risks. Biological Conservation 159:230-239.

PAPI, F., EDITOR. 1992. Animal homing. Chapman \& Hall, London.

Pierce, B.M., V.C. Bleich, J.D. Wehausen, and R.T. BOWYER. 1999. Migratory patterns of mountain lions: implications for social regulation and conservation. Journal of Mammalogy 80:986-992.

Riley, S.P.D., J.P. Pollinger, R.M. Sauvajot, E.C. York, C. Bromley, T.K. Fuller, and R.K. Wayne. 2006. A southern California freeway is a physical and social barrier to gene flow in carnivores. Molecular Ecology 15:1733-1741.
Riley, S.P.D., L.E.K. SERIEYS, J.P. Pollinger, J.A. Sikich, L. Dalbeck, R.K. Wayne, and H.B. Ernest. 2014. Individual behaviors dominate the dynamics of an urban mountain lion population isolated by roads. Current Biology 24:1989-1994.

Robinson, H.S., R. Desimone, C. Hartway, J.A. Gude, M.J. Thompson, M.S. Mitchell, and M. HebbleWHITE. 2014. A test of the compensatory mortality hypothesis in mountain lions: a management experiment in west-central Montana. Journal of Wildlife Management 78:791-807.

Ross, P.I., AND M.G. JALKOTZY. 1992. Characteristics of a hunted population of cougars in southwestern Alberta. Journal of Wildlife Management 56: $417-426$.

Ross, P.I., M.G. Jalkotzy, and M. FestaBianchet. 1997. Cougar predation on bighorn sheep in southwestern Alberta during winter. Canadian Journal of Zoology 75:771-775.

Ruth, T.K., K.A. Logan, L.L. Sweanor, M.G. HorNOCKER, AND L.J. TEMPLE. 1998. Evaluating cougar translocation in New Mexico. Journal of Wildlife Management 62:1264-1275.

Scali, S., R. Sacchi, M. Azzusi, S. Daverio, T. OppedisANO, AND M. MangIaCOTTI. 2013. Homeward bound: factors affecting homing ability in a polymorphic lizard. Journal of Zoology 289:196-203.

Seidensticker, J.C., M.G. Hornocker, W.V. Wiles, and J.P. MEssick. 1973. Mountain lion social organization in the Idaho primitive area. Wildlife Monographs 35:1-60.

Sikes, R.S., W.L. Gannon, and Animal Care and Use Committee of the American Society of MamMALOGISTS. 2011. Guidelines of the American Society of Mammalogists for the use of wild mammals in research. Journal of Mammalogy 92:235-253.

Spreadbury, B.R., K. Musil, J. Musil, C. Kaisner, and J. KovaK. 1996. Cougar population characteristics in southeastern British Columbia. Journal of Wildlife Management 60:962-969.

Stoner, D.C., W.R. Rieth, M.L. Wolfe, M.B. Mecham, AND A. NEVILLE. 2008. Long-distance dispersal of a female cougar in a Basin and Range landscape. Journal of Wildlife Management 72:933-939.

Stoner, D.C., M.L. Wolfe, and D.M. Choate. 2006. Cougar exploitation levels in Utah: implications for demographic structure, population recovery, and metapopulation dynamics. Journal of Wildlife Management 70:1588-1600.

Stoner, D.C., M.L. Wolfe, C.S. Mecham, M.B. Mecham, S.L. Durham, and D.M. Choate. 2013. Dispersal behaviour of a polygynous carnivore: do cougars Puma concolor follow source-sink predictions? Wildlife Biology 19:289-301.

Sweanor, L.L., K.A. Logan, J.W. Bauer, B. Millsap, and W.M. Boyce. 2008. Puma and human spatial and temporal use of a popular California State Park. Journal of Wildlife Management 72:1076-1084.

Sweanor, L.L., K.A. Logan, and M.G. Hornocker. 2000. Cougar dispersal patterns, metapopulation dynamics, and conservation. Conservation Biology 14:798-808.

Thibault, A., AND J. Bovet. 1999. Homing strategy of the eastern chipmunk, Tamias striatus (Mammalia: Rodentia): validation of the critical distance model. Ethology 105:73-82. 
Thompson, D.J., AND J.A. JEnks. 2005. Long-distance dispersal by a subadult male cougar from the Black Hills, South Dakota. Journal of Wildlife Management 69:818-820.

Thompson, D.J., And J.A. Jenks. 2010. Dispersal movements of subadult cougars from the Black Hills: the notions of range expansion and recolonization. Ecosphere 1:art8.

[USGS] United States Geological Survey. 2004. Precipitation history of the Mojave Desert Region, 1893-2001. http://pubs.usgs.gov/fs/fs117-03/.

WEar, B.J., R. EASTRIDGE, AND J.D. Clark. 2005. Factors affecting settling, survival, and viability of black bears reintroduced to Felsenthal National Wildlife Refuge, Arkansas. Wildlife Society Bulletin 33:1363-1374.
Weaver J.L., P.C. Paquet, and L.F. Ruggiero. 1996. Resilience and conservation of large carnivores in the Rocky Mountains. Conservation Biology 10 964-976.

White, G.E., And C. Brown. 2013. Site fidelity and homing behaviour in intertidal fishes. Marine Biology 160:1365-1372.

Received 23 December 2015

Revised 18 February 2018

Accepted 26 February 2018

Published online 9 August 2018 